\title{
Food insecurity and nutritional status of individuals in a socially vulnerable situation in Brazil
}

\author{
Insegurança Alimentar e estado nutricional entre indivíduos \\ em situação de vulnerabilidade social no Brasil
}

Kátia Godoy ${ }^{1}$

Karin Eleonora de Oliveira Sávio ${ }^{1}$

Rita de Cássia Akutsu ${ }^{1}$

Muriel Bauermann Gubert ${ }^{1}$

Raquel Braz Assunção Botelho ${ }^{1}$

${ }^{1}$ Departamento de

Nutrição, Faculdade

de Ciências da Saúde,

Universidade de Brasília.

Campus Universitário Darcy

Ribeiro, Asa Norte. 70910-

900 Brasília DF Brasil.

katiagc@gmail.com

\begin{abstract}
The objective was to investigate the association between food insecurity (FI) and anthropometric indicators among beneficiaries of a Brazilian social program called Community Canteens (CCs). This was a cross-sectional study. The associations were analyzed by chi-square test and Poisson regression. The subjects were 1,232 patrons of Brazil's CCs. Men with severe FI had a lower mean BMI $(-1.53 \mathrm{~kg} / \mathrm{m} 2)$ and a lower body fat percentage (-3.83 percentage points). Men that had a fat percentage classified as "risk of diseases associated with malnutrition" had a 2.34 times greater chance of experiencing severe FI, as did those who had low weight (PR: 2.64). However, these results were no longer significant after Poisson regression. With respect to women, there were no significant associations between the variables studied and FI. The high prevalence of overweight and body fat in the population at all of the FI levels and for both sexes are an indication of the complexity of the Brazilian scenario regarding the aspect of nutrition and excess weight in poor communities.
\end{abstract}

Key words Food insecurity, Nutritional status, Social vulnerability
Resumo O objetivo foi investigar a associação entre a insegurança alimentar (IA) e os indicadores antropométricos, entre os beneficiários do programa Restaurantes Populares, (RPs). Este foi um estudo transversal. As associações foram analisadas pelo teste do qui-quadrado e regressão de Poisson. Os sujeitos foram 1.232 usuários de RPs do Brasil. Homens com IA grave apresentaram menor média de IMC $(-1,53 \mathrm{~kg} / \mathrm{m} 2)$ e uma menor porcentagem de gordura corporal (- 3,83 pontos percentuais). Homens que apresentaram um percentual de gordura classificados como "risco de doenças associadas à desnutrição" tiveram 2,34 vezes mais chance de sofrer IA grave, assim como aqueles que apresentavam baixo peso (RP: 2,64). No entanto, estes resultados não permaneceram significativos após a regressão de Poisson. Quanto às mulheres, não houve associação significativa entre as variáveis estudadas e IA. A alta prevalência de sobrepeso e gordura corporal em todos os níveis de IA para ambos os sexos indica a complexidade do cenário brasileiro quanto ao aspecto nutricional, excesso de peso em comunidades carentes.

Palavras-chave Insegurança alimentar, Estado nutricional, vulnerabilidade social 


\section{Introduction}

Food insecurity is conditional to poverty. Thus, individuals in situations of social vulnerability present a greater likelihood of experiencing some level of food insecurity ${ }^{1,2}$. According to the National Household Survey (PNAD) of 2013', almost $22.6 \%$ of the Brazilian households show some level of food insecurity, but showing gradual decrease in relation to previous researches $(34.9 \%$ in 2004 and $30.2 \%$ in 2009) ${ }^{3}$. Besides the improvements, to identify theses groups and to know their needs can strengthen new public policies.

Brazil has several public policies that focus on low-income populations, such as food supply programs, in which community canteens (restaurantes populares, CCs) are included. These consist of food Service units, which have the objective of offering safe and healthy food at affordable prices (around US\$ 0.45 for a meal consisting of a main course, garnish, side dishes, dessert and juice). Access to the CCs is universal, but the priority users are the ones who are exposed to greater social vulnerability and situations of poverty. Thus, the recommended locations for these canteens are in areas with high circulation of people within large urban centers ${ }^{4}$.

In the current Brazilian epidemiological and nutritional context, conditions of overweight, obesity and non-transmissible chronic diseases (NTCDs) have been showing continuous progression, even among lower-income classes ${ }^{5,6}$. Therefore, identification and monitoring of the nutritional status of beneficiaries of social assistance programs, such as feeding and nutrition programs, becomes particularly necessary. These strategies should be truly appropriate for the real needs of these individuals and should not contribute towards risk factors for NTCDs?

In developed countries, studies have identified that women in situations of food insecurity present greater risk of presenting overweight/ obesity ${ }^{8,9}$. However, no single direction has yet been established with regard to results from male and infant groups ${ }^{9-12}$.

In low and medium-income countries, the situation is even more diverse. Some studies have shown a relationship between food insecurity and anthropometric and nutritional indicators for overweight and obesity ${ }^{13-15}$, while other studies have presented data showing significant associations between food insecurity and malnutrition and nutrient deficiency ${ }^{16,17}$.

Considering the gaps that still exist regarding food insecurity and nutritional status, including identification of body fat percentages, the objective of the present study was to investigate the possible relationship between household food insecurity and anthropometric indicators among users of a Brazilian social program called Community Canteens.

\section{Methods}

This was a cross-sectional study. It was a field research. The sample calculation was performed based on the official list of canteens connected to the CC Program of the Department for Social Development and Hunger Fighting (Ministério do Desenvolvimento Social e Combate à Fome, MDS) in 2008. The sample calculation was based on a universe composed of 65 canteens, with a maximum sample error of $5 \%$. Thus, the minimum simple random sample was estimated as 31 units. By the end of the data-gathering period, 32 CCs had been visited and investigated.

Brazil is divided in five geographic regions, North, Northeast, Centre-West, Southeast and South, which present characteristics that differ greatly from each other. The northern and northeastern regions generally present worse socioeconomic indicators because private and public investments were historically focused on the other regions, especially the southeastern and southern regions. Several public policies have been planned and implemented with the intention of reversing this situation, but great social and economic inequalities between the regions still remain ${ }^{18}$.

The sampled number of canteens (31) was proportionally divided among the five geographic regions, in order to guarantee representativeness of the target public, being 4 CCs on the North, 9 CCs on the Northeast, 1 CC on the Center-West, 12 CCs on the Southeast and 6 CCs on the South. For the present study, the sampling unit was defined as individuals who attended CCs at lunchtime. Thirty-seven customers per canteen participated in the study. This estimate for individuals per canteen was made using the G-Power 3.0.10 software, which uses statistical test parameters along with the power of the experiment. Since the study in the Centre-West region was carried out only in one canteen $(25 \%$ of the regional sample), the sampling error compromised the data (error estimated as $15 \%$ ), when the sampling unit was the individual. Therefore, although the data from the Centre-West region is presented, it should not be used for inferences. 
By the end of the sampling period, a total of 1,637 people had been randomly and systematically assessed. The sampling error for national representativeness was less than 3\% (the total number of users of the CC program in the country was 55,350 individuals/day). For the present study, elderly individuals $(\mathrm{n}=405)$, participants over 60 years old, were excluded, because of the characteristic variations that occur in body composition in this age group ${ }^{19}$, which would have compromised the analysis on the variable of "fat percentage". Thus, 1,232 individuals remained in the study.

The users were approached for sampling in a systematic order: one individual for every 15 that entered the restaurant on the day of data-gathering. If the selected user refused to participate in the study, the next user was approached, followed by the $30^{\text {th }}$ and the $45^{\text {th }}$ users, consecutively. Regarding the inclusion criteria, users that had lunch with a minimum frequency of three times a week at the CC were considered eligible because they were frequent customers. Pregnant women were not considered eligible for the research because of their distinct anthropometry and people below the age of 18 were not considered because they required an authorization from their legal guardians.

Socioeconomic and anthropometric variables and the household food insecurity were analyzed. Regarding the age group, users were classified as young adults (18-30 years) and adults (31-59 years). Regarding marital status, single, widowed and separated users were combined in a single group, since they presented a similar family composition (single-parent household). Considering the educational level, the sample was divided in users with less than 8 years of formal education (which corresponds to elementary education in Brazil) and users with 8 years or more of formal education (high school or higher). The per capita income was categorized as extreme poverty, i.e. up to $1 / 4$ of the minimum monthly wage (around US\$ 75); poverty, i.e. between $1 / 4$ and $1 / 2$ of the minimum monthly wage (approximately US\$ 75 to 150); and greater than $1 / 2$ of the minimum monthly wage, i.e. more than U\$ 150 . These bands were based on the cutoff points used by the Brazilian government to select eligible individuals for social programs. Regarding the geographic regions, these were grouped as North and Northeast (North/Northeast) and as Centre-West, Southeast and South (Centre-South) because of the aforementioned particularities of each of these regions.
A questionnaire was applied to obtain the study variables. Nutrition professionals in a separate environment carried out anthropometric evaluations before these users had lunch. BMI was classified in accordance with the criteria adopted by the World Health Organization ${ }^{20}$. Fat percentage was conducted by bioelectrical impedance analysis (tetra polar body) and classified in accordance with Lohman et al. ${ }^{21}$ : risk of diseases and disorders associated with malnutrition ( $\leq 5 \%$ for men and $\leq 8 \%$ for women), below average (6\%-14\% for men and 9\%-22\% for women), average ( $15 \%$ for men and $23 \%$ for women), above average (16\%-24\% for men and $24 \%-31 \%$ for women) and risk of diseases associated with obesity ( $\geq 25 \%$ for men and $\geq 32 \%$ for women).

The dependent variable of this study was food insecurity. The Brazilian Scale for Food Insecurity (Escala Brasileira de Insegurança Alimentar, EBIA) was used to evaluate it. This tool, which is a psychometric scale containing 14 questions, directly evaluates the situation of food insecurity experienced by a household over the past three months ${ }^{22}$. The scale presents 14 items and has different cutoff points for households with or without individuals below 18 years of age. It allows the household's situation to be classified as one of food security, mild food insecurity, moderate food insecurity and severe food insecurity. This questionnaire is an adapted version of the U.S. Household Food Security Module (HHFSM) used by the United States Department of Agriculture (USDA) ${ }^{14,16,23,24}$.

Descriptive data analysis was carried out to characterize the sample. The categorized variables were compared regarding their prevalence ratios using Pearson's chi-square test and the likelihood ratio. The mean differences were tested using ANOVA test. Poisson's regression was used to calculate the adjusted prevalence ratio for the outcome of severe food insecurity $(\mathrm{p}<0.05)$. Variables included in Poisson's regression were the ones with $p<0.20$ for the analysis of each sex. For women, the category "below average" in terms of body fat was grouped with the normal category because of the small number of cases. Moreover, no cases of "risk of diseases associated with malnutrition" were found among women, according to the body fat percentage. The independent variables included in the regression were: marital status, geographic region and age group. The software used for the data analyses was SPSS version 17.0 (SPSS Inc., Chicago, United States).

This study was approved by the Research Ethics Committee of the Health School of the University of Brasília in May 2010. 


\section{Results}

The sample consisted of 1,232 users, of whom 523 were women and 709 were men. Among men, $40.6 \%$ presented some level of food insecurity ( $9.6 \%$ with severe FI). The variables of educational level and per capita income presented significant differences $(\mathrm{p}<0.001)$ among the levels of domestic food insecurity. Among women, $43.8 \%$ presented some level of food insecurity (7.3\% with severe FI) and, similarly to males, the variables of educational level and per capita income, along with living in different regions of Brazil, presented significant differences among the levels of food insecurity (Table 1).

Men with severe food insecurity presented lower mean weight $(-7.0 \mathrm{~kg})$, lower mean BMI $\left(-1.6 \mathrm{~kg} / \mathrm{m}^{2}\right)$ and lower body fat percentage $(-3.9$ percentage points) than the secure ones, all with significant differences. Women did not present significant differences in body composition or BMI according to FI levels (Table 2).

Men, in food security and at all levels of food insecurity with the exception of severe food insecurity, presented mean BMI greater than normal $\left(\mathrm{BMI} \geq 25 \mathrm{~kg} / \mathrm{m}^{2}\right)$ and mean fat percentages that were considered to be "above average" (16-24\%). Only men with severe food insecurity presented mean BMI within the category of normal weight $\left(23.9 \mathrm{~kg} / \mathrm{m}^{2}\right)$ and a fat percentage "below average" (mean body fat of $13.8 \%$ ) (Table 2 ).

Women, in food security and at all levels of FI, presented mean BMI greater than normal weight range $\left(\mathrm{BMI} \geq 25 \mathrm{~kg} / \mathrm{m}^{2}\right)$ and mean fat percentages "above average" (24-31\%) ${ }^{23}$. Those with mild FI presented higher values of body fat (mean of $32.4 \%$ ), corresponding to the classification "risk of diseases associated with obesity" (Table 2).

For prevalence ratio (PR) and adjustable analysis, only severe food insecurity was used because it was associated to variables such as weight and body fat using bivariate analysis (data not shown). Men who presented fat percentage classified as "risk of diseases associated with malnutrition" had a 2.34 times greater chance (CI: 1.32-4.14; $\mathrm{p}=0.007)$ of experiencing severe FI, in comparison with those with a normal percentage. Similarly, men who presented underweight had a 2.64 times greater chance (CI: 1.32-4.14; p $=0.007)$ of experiencing severe FI, in comparison with those with normal BMI. However, these results did not remain significant after multivariate regression. Regarding women, no significant associations were found between the variables studied and FI (Table 3).

\section{Discussion}

In both sexes, there was a significant association between food insecurity and the variables of income and educational level. This result was expected because food insecurity is intrinsically related to income, since FI scales measure the level of food restriction quantitatively and qualitatively, especially caused by income limitation ${ }^{25,26}$. Educational level results show a similar pattern, considering that educational level is a proxy for income ${ }^{18}$.

Regarding the Brazilian geographic regions where the subjects lived, only women presented any significant association between this variable and food insecurity. Women living in the North/ Northeast region seemed to present a worse profile of food insecurity than those living in the Centre-South region. This result indicates accumulation of two characteristics of vulnerability in Brazil: being a woman and living in the North/ Northeast region of the country ${ }^{18}$. These data are in agreement with the findings from other Brazilian studies, including a population-based study (the National Household Sampling Survey) that presented a diagnosis for food security among the Brazilian population in 2004, 2009 and $2013^{3,27}$. Among other findings, there was greater prevalence of FI among women than among men in the northern and northeastern regions of the country, in comparison with the remaining geographic regions.

The adjusted analysis did not indicate any significant differences in FI with regard to BMI and body fat percentage. Both BMI and fat percentages have implications regarding associated morbidity load, which should not be disregarded.

In this context, regarding food insecurity and nutritional status, findings show that men in a situation of severe food insecurity present lower mean weight and lower mean fat percentage than those in a situation of food security. It is important to note that the mean BMI was within the normal weight range, while the fat percentages related to the classification "below average" (but not malnutrition), unlike several studies that have indicated an association between FI and malnutrition $^{16,17}$. Thus, the present study demonstrated that there is a greater chance that male CC users in Brazil who are in a situation of severe food insecurity will present lower weight and fat percentages than those in a situation of food security.

It is important to highlight, however, that in the other groups of food insecurity, the mean values for BMI and fat percentages were mostly 
Table 1. Household food insecurity according to the socioeconomic variables presented by users of the community canteens. Brazil.

\begin{tabular}{|c|c|c|c|c|c|c|c|c|c|}
\hline & \multicolumn{8}{|c|}{ Men (709) } & \multirow{4}{*}{$\mathrm{P}^{\mathrm{a}}$} \\
\hline & \multirow{2}{*}{\multicolumn{2}{|c|}{$\begin{array}{c}\text { Food } \\
\text { Security }\end{array}$}} & \multicolumn{6}{|c|}{ Food Insecurity } & \\
\hline & & & \multicolumn{2}{|c|}{ Mild } & \multicolumn{2}{|c|}{ Moderate } & \multicolumn{2}{|c|}{ Severe } & \\
\hline & $\mathbf{n}$ & $\%$ & $\mathbf{n}$ & $\%$ & $\mathbf{n}$ & $\%$ & $\mathbf{n}$ & $\%$ & \\
\hline Total & 421 & 59.4 & 126 & 17.8 & 94 & 13.3 & 68 & 9.6 & \\
\hline \multicolumn{10}{|l|}{ Age group } \\
\hline $31-59$ years & 282 & 58.0 & 82 & 16.9 & 68 & 14.0 & 54 & 11.1 & \multirow[b]{2}{*}{0.137} \\
\hline $18-30$ years & 139 & 62.3 & 44 & 19.7 & 26 & 11.7 & 14 & 6.3 & \\
\hline \multicolumn{10}{|l|}{ Marital status } \\
\hline With partner & 186 & 60.6 & 59 & 19.2 & 41 & 13.4 & 21 & 6.8 & \multirow[b]{2}{*}{0.166} \\
\hline Single/widow/divorced & 234 & 58.4 & 67 & 16.7 & 53 & 13.2 & 47 & 11.7 & \\
\hline \multicolumn{10}{|l|}{ Educational level } \\
\hline Less than 8 years of education & 167 & 49.0 & 68 & 19.9 & 54 & 15.8 & 52 & 15.2 & \multirow[b]{2}{*}{$<0.001$} \\
\hline 8 years of education or more & 254 & 69.0 & 58 & 15.8 & 40 & 10.9 & 16 & 4.3 & \\
\hline \multicolumn{10}{|l|}{ Per capita income } \\
\hline Extreme poverty (up to $1 / 4 \mathrm{MW}$ ) & 34 & 35.8 & 22 & 23.2 & 18 & 18.9 & 21 & 22.1 & \multirow{3}{*}{$<0.001$} \\
\hline Poverty $(1 / 4$ to $1 / 2 \mathrm{MW})$ & 66 & 45.2 & 32 & 21.9 & 29 & 19.9 & 19 & 13.0 & \\
\hline Above $1 / 2 \mathrm{MW}$ & 321 & 68.6 & 72 & 15.4 & 47 & 10.0 & 28 & 6.0 & \\
\hline \multicolumn{10}{|l|}{ Region in Brazil } \\
\hline North/Northeast & 164 & 54.8 & 54 & 18.1 & 49 & 16.4 & 32 & 10.7 & \multirow[b]{2}{*}{0.098} \\
\hline \multirow[t]{5}{*}{ Centre-South } & 257 & 62.7 & 72 & 17.6 & 45 & 11.0 & 36 & 8.8 & \\
\hline & \multicolumn{8}{|c|}{ Women (523) } & \multirow{4}{*}{$\mathbf{p}$} \\
\hline & \multirow{2}{*}{\multicolumn{2}{|c|}{$\begin{array}{c}\text { Food } \\
\text { Security }\end{array}$}} & \multicolumn{6}{|c|}{ Food Insecurity } & \\
\hline & & & \multicolumn{2}{|c|}{ Mild } & Mod & rate & & ere & \\
\hline & $\mathbf{n}$ & $\%$ & $\mathbf{n}$ & $\%$ & $\mathbf{n}$ & $\%$ & $\mathbf{n}$ & $\%$ & \\
\hline Total & 294 & 56.2 & 115 & 22.0 & 76 & 14.5 & 38 & 7.3 & \\
\hline Age group & & & & & & & & & \\
\hline $31-59$ years & 187 & 55.5 & 76 & 22.6 & & 13.6 & 28 & 8.3 & \\
\hline $18-30$ years & 107 & 57.5 & 39 & 21.0 & & 16.1 & 10 & 5.4 & 0.542 \\
\hline Marital status & & & & & & & & & \\
\hline With partner & 117 & 53.7 & 53 & 24.3 & & 15.1 & 15 & 6.9 & \\
\hline Single/widow/divorced & 177 & 58.0 & 62 & 20.3 & & 14.1 & 23 & 7.5 & 0.678 \\
\hline Educational level & & & & & & & & & \\
\hline Less than 8 years of education & 93 & 43.7 & 48 & 22.5 & & 19.7 & 30 & 14.1 & \\
\hline 8 years of education or more & 201 & 64.8 & 67 & 21.6 & & 11.0 & 8 & 2.6 & $<0.001$ \\
\hline Per capita income & & & & & & & & & \\
\hline Extreme poverty (up to $1 / 4 \mathrm{MW}$ ) & 35 & 38.5 & 25 & 27.5 & & 15.4 & 17 & 18.7 & \\
\hline Poverty ( $1 / 4$ to $1 / 2 \mathrm{MW})$ & 61 & 45.2 & 34 & 25.2 & & 19.3 & 14 & 10.4 & \\
\hline Above $1 / 2 \mathrm{MW}$ & 198 & 66.7 & 56 & 18.9 & & 12.1 & 7 & 2.4 & $<0.001$ \\
\hline Region in Brazil & & & & & & & & & \\
\hline North/Northeast & 120 & 48.8 & 57 & 23.2 & & 19.1 & 22 & 8.9 & 0,004 \\
\hline Centre-South & 174 & 62.8 & 58 & 20.9 & & 10.5 & 16 & 5.8 & 0.004 \\
\hline
\end{tabular}

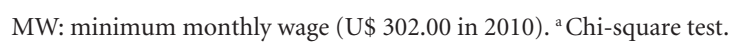

classified as above normal values, which indicates the existence of a tendency towards overweight, even in the groups with food insecurity. Studies so far that have investigated the relationship be- 
Table 2. Anthropometric profile according to gender and state of food insecurity among users of the community canteens. Brazil.

\begin{tabular}{|c|c|c|c|c|c|c|c|c|}
\hline \multirow[b]{3}{*}{ Measurement } & & & & \multicolumn{5}{|c|}{ Food Insecurity } \\
\hline & \multicolumn{2}{|c|}{ Food Security ${ }^{a}$} & \multicolumn{2}{|c|}{ Mild } & \multicolumn{2}{|c|}{ Moderate } & \multicolumn{2}{|c|}{ Severe } \\
\hline & Mean & $\mathrm{SD}^{\mathrm{b}}$ & Mean & $\mathrm{SD}^{\mathrm{b}}$ & Mean & $\mathrm{SD}^{\mathrm{b}}$ & Mean & $\mathrm{SD}^{\mathrm{b}}$ \\
\hline Men (709) & \multicolumn{2}{|c|}{$\mathrm{n}=421$} & \multicolumn{2}{|c|}{$\mathrm{n}=126$} & \multicolumn{2}{|c|}{$\mathrm{n}=94$} & \multicolumn{2}{|c|}{$\mathrm{n}=68$} \\
\hline Weight (kg) & 75.0 & 13.7 & 73.6 & 14.3 & 72.2 & 11.5 & $68.0^{\star}$ & 13.6 \\
\hline $\mathrm{BMI}\left(\mathrm{kg} / \mathrm{m}^{2}\right)$ & 25.5 & 4.6 & 25.6 & 4.5 & 25.3 & 3.8 & $23.9^{\star}$ & 7.6 \\
\hline Fat (\%) & 17.7 & 6.6 & 16.9 & 6.4 & 17.7 & 6.9 & $13.8^{\star}$ & 7.6 \\
\hline Women (523) & \multicolumn{2}{|c|}{$\mathrm{n}=294$} & \multicolumn{2}{|c|}{$\mathrm{n}=115$} & \multicolumn{2}{|c|}{$\mathrm{n}=76$} & \multicolumn{2}{|c|}{$\mathrm{n}=38$} \\
\hline Weight (kg) & 65.7 & 14.3 & 65.1 & 13.4 & 64.13 & 13.1 & 62.8 & 13.9 \\
\hline BMI $\left(\mathrm{kg} / \mathrm{m}^{2}\right)$ & 26.0 & 5.8 & 26.3 & 5.0 & 26.13 & 5.4 & 25.7 & 5.9 \\
\hline Fat (\%) & 31.0 & 8.2 & 32.4 & 9.1 & 31.43 & 8.3 & 30.0 & 9.4 \\
\hline
\end{tabular}

${ }^{\mathrm{a}}$ Comparison group. ${ }^{\mathrm{b}} \mathrm{SD}$ : standard deviation. ${ }^{*} \mathrm{P} \leq 0.05$, ANOVA test.

tween FI and nutritional status among men have presented varying results. Wilde and Peterman $^{28}$ found that American men in a situation of marginal food security were more likely to be obese than were those in situations of total food security. In turn, Tayie and Zizza ${ }^{29}$ published data similar to those obtained through the present study, in which American men in situations of food insecurity were found to have significantly lower body fat than men in situations of food security.

The data found in the present study seem to be in accordance with the Brazilian reality, in which overweight and obesity among men is less prevalent in lower income groups. Low income is a variable strongly associated with food insecurity. Household Budget Survey of 2008/2009 3 indicated that $30.9 \%$ of the population group that received $1 / 4$ of the minimum monthly wage presented overweight and that this percentage increased progressively reaching $63.2 \%$ of the population group that received 5 or more minimum monthly wages.

Women did not present significant differences in BMI or body fat percentages, even comparing the extremities of food security and severe FI. However, in all situations of food insecurity/ security, BMI and fat percentages were classified as excessive, at limits nearing the category of risk of diseases associated with obesity. In Brazil, the Family Budget Survey of 2008/20095 had already indicated that women presented greater prevalence of obesity, in relation to men, while men presented greater proportions of overweight in relation to women. It is important to note that greater percentages of overweight and obesity were observed in the intermediate income groups of that study, for women. In the present study, a similar result was found, since the greatest mean values of BMI and fat percentages among women related to the intermediate levels of FI (mild and moderate FI), although the results were not statistically different between each other.

Among women in developing countries, several studies have indicated a relationship between moderate levels of FI and overweight ${ }^{10,30}$. In Brazil, according to the National Demographics and Health Survey of $2006^{31,32}$, within the research group of Demographic Health Surveys (DHSs), there were associations between moderate FI and obesity among women ${ }^{14}$ and between severe FI and obesity among female adolescents ${ }^{31}$. In a survey carried out by Santos et al. ${ }^{31}$ in homes with food insecurity in the southern region of Brazil, there were greater prevalence rates of obesity among women $(31 \%)$ than among men (12\%).

Few studies have considered the relationship between body fat percentage and FI. In a study carried out in rural areas of Malaysia among women in homes with food insecurity, a positive association was observed between food insecurity and greater waist circumference; however, body fat percentage was not assessed ${ }^{12}$. A population-based study carried out in the United States among men and women did not find any significant association between food insecurity and fat percentage among women. However, for men, the greater the severity of food insecurity was, the lower the body fat also was ${ }^{29}$.

One of the possible explanatory factors for the greater fat percentage associated with food 
Table 3. Crude and adjusted prevalence ratios and $95 \%$ confidence interval for severe food insecurity according to the classifications of BMI and fat percentage among users of the community canteens. Brazil.

\begin{tabular}{|c|c|c|c|c|c|}
\hline & \multicolumn{5}{|c|}{ Severe Food Insecurity } \\
\hline & \multicolumn{5}{|c|}{ Men (68) } \\
\hline & n (\%) & $\mathrm{PR}^{\mathrm{f}}(\mathrm{CI})$ & $\mathbf{p}$ & Adjusted PR (CI) ${ }^{\mathrm{g}}$ & $\mathbf{p}$ \\
\hline \multicolumn{6}{|l|}{ Fat percentage } \\
\hline $\begin{array}{l}\text { Risk of diseases and } \\
\text { disorders associated with } \\
\text { malnutrition }{ }^{\mathrm{a}}\end{array}$ & $10(14.7)$ & $2.34(1.32-4.14)$ & 0.007 & $1.18(0.82-1.71)$ & 0.362 \\
\hline Below average Mean $^{\mathrm{b}}$ & $31(45.6)$ & 1 & - & 1 & - \\
\hline Above average $^{\mathrm{c}}$ & $23(33.8)$ & $0.62(0.37-1.01)$ & 0.054 & $0.94(0.77-1.14)$ & 0.514 \\
\hline $\begin{array}{l}\text { Risk of diseases associated } \\
\text { with obesity }\end{array}$ & $4(5.9)$ & $0.28(0.10-0.76)$ & 0.005 & $0.89(0.69-1.14)$ & 0.351 \\
\hline \multicolumn{6}{|l|}{ BMI } \\
\hline Underweight & $7(10.3)$ & $2.64(1.32-4.14)$ & 0.007 & $1.2(0.79-1.83)$ & 0.390 \\
\hline Normal weight range & $36(52.9)$ & 1 & - & 1 & \\
\hline \multirow[t]{3}{*}{ Excess weight ${ }^{e}$} & $25(36.8)$ & $0.67(0.42-1.08)$ & 0.095 & $0.95(0.80-1.13)$ & 0.537 \\
\hline & \multicolumn{5}{|c|}{ Women (38) } \\
\hline & n (\%) & $\mathrm{PR}^{\mathrm{f}}(\mathrm{CI})$ & p & Adjusted PR (CI) ${ }^{g}$ & p \\
\hline \multicolumn{6}{|l|}{ Fat percentage } \\
\hline $\begin{array}{l}\text { Risk of diseases and } \\
\text { disorders associated with } \\
\text { malnutrition }^{\text {a }}\end{array}$ & - & - & - & - & - \\
\hline Below average + Mean $^{\mathrm{b}}$ & $7(19.0)$ & 1 & - & 1 & - \\
\hline Above average $^{c}$ & $15(40.5)$ & $1.22(0.52-2.84)$ & 0.644 & $1.0(0.75-1.35)$ & 0.985 \\
\hline $\begin{array}{l}\text { Risk of diseases associated } \\
\text { with obesity }{ }^{\mathrm{d}}\end{array}$ & $15(40.5)$ & $0.95(0.41-2.22)$ & 0.904 & $0.97(0.72-1.31)$ & 0.842 \\
\hline \multicolumn{6}{|l|}{ BMI } \\
\hline Underweight & $2(5.3)$ & $1.09(0.28-4.29)$ & 0.904 & $1.0(0.61-1.64)$ & 0.987 \\
\hline Normal weight range & $17(44.7)$ & 1 & - & & \\
\hline Excess weight ${ }^{e}$ & $19(50.0)$ & $0.99(0.53-1.82)$ & 0.961 & $0.99(0.79-1.23)$ & 0.893 \\
\hline
\end{tabular}

insecurity among women, though far from being the only one, could be the number of children. Women with children present higher overweight and obesity rates in FI situations, in comparison with women without children and with men ${ }^{30}$. Although the present study did not identify the presence and number of children, the Brazilian Demographic Census carried out in 2010 indicated that low-income women have a greater number of children than those in higher income groups $^{33}$. This, combined with low income, less physical activity and diets of limited quality, which are characteristics of vulnerable popula- tions in Brazil, results in a set of potential triggers for overweight among women ${ }^{5,33,34}$.

These data indicate the complexity of the context of the study group, which was composed of individuals who were assumed to be at greater risk of social vulnerability, since they were beneficiaries of a feeding and nutrition program that focuses on poor populations, although access is universal. This situation of coexistence of food insecurity and overweight has been widely investigated. According to Popkin et al. ${ }^{7}$, it has been established in the scientific literature that the environments to which individuals are exposed, 
from the phase of conception to adulthood, influence the risk of obesity and other NTCDs. Several studies have indicated that food restriction during the fetal phase lead to greater risk of overweight and NTCDs during adulthood ${ }^{33}$.

This reality can be particularly harmful among lower-income classes. Because of financial limitations, these people consume food with low nutritional value, but with high energy density, since these are cheaper ${ }^{7}$. The price of food seems to strongly influence food consumption worldwide, especially among individuals of lower-income classes and in developing countries ${ }^{35,36}$. The modifications that technological advancements have brought to food processing have decreased the price of industrialized, ready-to-eat products, which are usually rich in fats, sugar and salt and poor in micronutrients and fibers. Claro and Monteiro $^{36}$ observed that fruits and vegetables were purchased less often among low-income Brazilian families as the price of these foods increased. The price variable is highly related to food insecurity.

Therefore, the importance of this association has been made clear, and immediate social support strategies such as CCs, as well as longterm strategies such as jobs' creation, increased educational level and access to health and education. Equally important are actions that promote healthy eating habits, which should include policies for broadening the access to healthier foods and also incentives for consumption. Nutritional education is essential for these goals. Social empowerment and the incorporation of healthier eating habits among groups in social vulnerability is a necessary goal in order to break the double burden of diseases and the overload of consequences that they bring ${ }^{37}$.

The present study has some limitations, such as its cross-sectional design, which does not allow causal judgments among the associations. The fact that it was necessary to exclude the elderly from the sample due to the physiological peculiarities that are characteristic at this age (which could have interfered with the anthropometric indicators) reduced the original sample by $25 \%$. The number of children was not obtained in this study being a limitation for comparison among women. Although the data from the Centre-West region is presented, it should not be used for inferences.

\section{Conclusions}

Significant associations among FI and anthropometric variables used in this population (frequent users of federal canteens in Brazil) were not identified. However, high prevalence of overweight and body fat in population in all the FI levels and for both sexes indicate the complexity of the Brazilian nutritional scenario, excess weight in poor communities. These data show the need for actions to fight excess weight and to promote healthy eating among population under poverty. Due to the nutritional status of canteen users, nutritional educational actions should be developed as an alternative in this environment.

\section{Collaborations}

K Godoy worked in data collection and analysis. KEO Sávio and RBA Botelho worded in study design and analysis. RC Akutsu and MB Gubert worked in study design and statistical analysis. 


\section{References}

1. Corrêa AMS. Insegurança alimentar medida. Estudos avançados 2007; 21(60):143.

2. Carter MA, Dubois L, Tremblay MS. Place and food insecurity: a critical review and synthesis of the literature. Public Health Nutr 2014; 17(01):94-112.

3. Instituto Brasileiro de Geografia e Estatística (IBGE). Pesquisa Nacional por Amostra de Domicílios. Suplemento de Segurança Alimentar e Nutricional da Pesquisa Nacional de Amostra por Domicílios-PNAD 2013. Rio de Janeiro: IBGE; 2014.

4. Belik W. Projeto Fome Zero: o desenho de uma política de segurança alimentar e nutricional para o Brasil. In: Brasil. Ministério do Desenvolvimento Social (MDS) Fome Zero: uma história brasileira. Brasília: MDS; 2011. p. $176-188$.

5. Instituto Brasileiro de Geografia e Estatística (IBGE). Pesquisa de orçamentos familiares 2008-2009: Análise do consumo alimentar pessoal no Brasil. Rio de Janeiro: IBGE; 2011.

6. Steele EM, Claro RM, Monteiro CA. Behavioural patterns of protective and risk factors for non-communicable diseases in Brazil. Public Health Nutr 2014; 17(02):369-375

7. Popkin BM, Adair LS, Ng SW. Global nutrition transition and the pandemic of obesity in developing countries. Nutr Rev 2012; 70(1):3-21.

8. Olson S, Miller EA, Troy LM. Hunger and Obesity: Understanding a Food Insecurity Paradigm. Workshop Summary. Washington: National Academies Press; 2011.

9. Laraia BA. Food insecurity and chronic disease. Advances in Nutrition: Int Rev I 2013; 4(2):203-212.

10. Dinour LM, Bergen D, Yeh M-C. The food insecurity-obesity paradox: a review of the literature and the role food stamps may play. J Am Diet Assoc 2007; 107(11):1952-1961.

11. Eisenmann JC, Gundersen C, Lohman BJ, Garasky S, Stewart SD. Is food insecurity related to overweight and obesity in children and adolescents? A summary of studies, 1995-2009. Obesity Rev 2011; 12(5):e73-e83.

12. Dubois L, Francis D, Burnier D, Tatone-Tokuda F, Girard M, Gordon-Strachan G, Fox K, Wilks R. Household food insecurity and childhood overweight in Jamaica and Quebec: a gender-based analysis. BMC Public Health 2011; 11(1):1.

13. Leyna GH, Mmbaga EJ, Mnyika KS, Hussain A, Klepp KI. Food insecurity is associated with food consumption patterns and anthropometric measures but not serum micronutrient levels in adults in rural Tanzania. Public Health Nutr 2010; 13(09):1438-1444.

14. Velásquez-Melendez G, Schlüssel MM, Brito AS, Silva AA, Lopes-Filho JD, Kac G. Mild but not light or severe food insecurity is associated with obesity among Brazilian women. J Nutr 2011; 141(5):898-902.

15. Schlüssel MM, Silva AAMd, Pérez-Escamilla R, Kac A. Household food insecurity and excess weight/obesity among Brazilian women and children: a life-course approach. Cad Saude Publica 2013; 29(2):219-226.

16. Gulliford MC, Mahabir D, Rocke B. Food insecurity, food choices, and body mass index in adults: nutrition transition in Trinidad and Tobago. Int J Epidemiol 2003; 32(4):508-516
17. Isanaka S, Mora-Plazas M, Lopez-Arana S, Baylin A, Villamor E. Food insecurity is highly prevalent and predicts underweight but not overweight in adults and school children from Bogota, Colombia. J Nutr 2007; 137(12):2747-2755.

18. Instituto Brasileiro de Geografia e Estatística (IBGE). Uma análise das condições de vida da população brasileira. Rio de Janeiro: IBGE; 2013.

19. Lustgarten MS, Fielding RA. Assessment of analytical methods used to measure changes in body composition in the elderly and recommendations for their use in phase II clinical trials. J Nutr Health Aging 2011; 15(5):368-375

20. Committee WE. Physical status: the use and interpretation of anthropometry. WHO technical report series. 1995; 854(121):55.

21. Lohman T, Roache A, Martorell R. Anthropometric Standardization Reference Manual. Medicine \& Science in Sports \& Exercise. 1992; 24(8):952.

22. Pinto AR, Pereira AK, RS C. Análise de indicadores $e$ dos resultados do Suplemento de Segurança Alimentar e Nutricional da Pesquisa Nacional de Amostra por Domicílios-PNAD 2013/2014. Brasília: Ministério do Desenvolvimento Social; 2009.

23. Segall-Corrêa AM, Marin-León L, Melgar-Quiñonez H, Pérez-Escamilla R. Refinement of the Brazilian Household Food Insecurity Measurement Scale: Recommendation for a 14-item EBIA. Rev Nutr 2014; 27(2):241-251

24. Pérez-Escamilla R, Segall-Corrêa AM, Maranha LK, Sampaio MMF, Marín-León L, Panigassi G. An adapted version of the US Department of Agriculture Food Insecurity module is a valid tool for assessing household food insecurity in Campinas, Brazil. J Nutr 2004; 134(8):1923-1928.

25. Salles-Costa R, Pereira RA, Vasconcellos MTL, Veiga GV, Marins VMR, Jardim BC, Gomes FS, Sichieri R. Associação entre fatores socioeconômicos e insegurança alimentar: estudo de base populacional na Região Metropolitana do Rio de Janeiro, Brasil. Rev nutr 2008; 21(Supl.):99s-109s.

26. Vianna RPT, Segall-Corrêa AM. Insegurança alimentar das famílias residentes em municípios do interior do estado da Paraíba, Brasil. Rev nutr 2008; 21(Supl.):111s$122 \mathrm{~s}$.

27. Instituto Brasileiro de Geografia e Estatística (IBGE). Pesquisa Nacional por Amostra de Domicílios - Suplemento de Segurança Alimentar 2004/2009. Rio de Janeiro: IBGE; 2010.

28. Wilde PE, Peterman JN. Individual weight change is associated with household food security status. J Nutr 2006; 136(5):1395-1400.

29. Tayie FA, Zizza CA. Height differences and the associations between food insecurity, percentage body fat and BMI among men and women. Public health Nutr 2009; 12(10):1855-1861.

30. Martin MA, Lippert AM. Feeding her children, but risking her health: The intersection of gender, household food insecurity and obesity. Soc Sci Med 2012; 74(11):1754-1764 
31. Santos JVd, Gigante DP, Domingues MR. Prevalence of food insecurity in Pelotas, Rio Grande do Sul State, Brazil, and associated nutritional status. Cad Saude Publica 2010; 26(1):41-49.

32. Brasil. Ministério da Saúde (MS). Pesquisa Nacional de Demografia e Saúde da Criança e da Mulher-PNDS 2006: dimensões do processo reprodutivo e da saúde da criança. Brasília: MS; 2009.

33. Waterland RA. Is epigenetics an important link between early life events and adult disease? Horm Res 2009; 71(Supl. 1):13-16.

34. Datasus. VIGITEL-vigilancia de fatores de risco e proteção para doenças crônicas por inquérito telefônico. Brasília: Datasus; 2010.

35. Drewnowski A, Specter S. Poverty and obesity: the role of energy density and energy costs. Am J Clin Nutr 2004; 79(1):6-16.

36. Claro RM, Monteiro CA. Renda familiar, preço de alimentos e aquisição domiciliar de frutas e hortaliças no Brasil. Rev Saude Publica 2010; 44(6):1014-1020.

37. Coutinho JG, Gentil PC, Toral N. A desnutrição e obesidade no Brasil: o enfrentamento com base na agenda única da nutrição Malnutrition and obesity in Brazil: dealing with the problem through. Cad Saude Publica 2008; 24(Supl. 2):S332-S340.

Artigo apresentado em 26/06/2016

Aprovado em 16/09/2016

Versão final apresentada em 18/09/2016 